\author{
Anna Lewicka-Strzałecka \\ Polish Academy of Sciences \\ Institute of Philosophy and Sociology \\ e-mail: alewicka@ifispan.waw.pl
}

\title{
Świadomość konfliktu interesów jako akademicki standard etyczny
}

\section{Awareness of Conflict of Interest as an Academic Standard of Ethics}

The paper shows that conflicts of interest in science undermine its ethos. Some examples of this phenomenon have been analysed from the point of view of its destructive consequences. The need to counter them has also been identified in our country and some legal regulations and self-regulations are gradually being introduced. However, they are not always respected in practice. In the last part of the paper a model of management of risk of bias in scientific research has been outlined. The main thesis says that an awareness of conflict of interest embracing both knowledge of the general issues and relevant assessment of personal risk of lack of objectivism should be an ethical minimum of every scientific worker.

Keywords: conflict of interest, funding effect, ethical standard, ethos of science

JEL Classification: I23

\section{Wstęp}

Konflikty interesów zawsze były obecne w nauce, jednak postępująca jej komercjalizacja i towarzyszące temu procesowi przekształcanie wiedzy w wartość mającą przynosić zysk znacznie zwiększyły ich liczbę, zasięg i moc oddziaływania. Coraz więcej badań finansowanych jest przez przemysł, który kieruje środki na taką problematykę, na której da się zarobić, a także jest zainteresowany określonymi, czyli korzystnymi dla siebie wynikami badań. Prowadzi to do zakwestionowania etosu nauki wraz z jej podstawowymi wartościami bezinteresowności i obiektywizmu. 
Konflikt interesów w nauce może być źródłem tendencyjności i w efekcie prowadzić do poważnych zniekształceń wyników badań. Godzi to w wewnętrzną spójność i integralność nauki, gdyż prowadząc badania naukowe, czy też wykorzystując ich wyniki, wciąż opieramy się na świadectwie innych, czyli powinniśmy mieć do tego świadectwa zaufanie ${ }^{1}$. Nauka nie jest kwestią wiary, ale przeciętny człowiek swój stosunek do niej musi opierać na wierze w wyniki badań naukowych, gdyż nie jest w stanie ich kontrolować. Zniekształcone czy wręcz fałszywe wyniki takich badań podważają wiarygodność nauki i osłabiają zaufanie jakim darzy ją społeczeństwo, a co za tym idzie mogą osłabiać udzielane jej wsparcie. Chociaż całkowite wyeliminowanie konfliktu interesów z nauki, podobnie jak i z innych obszarów ludzkiego działania, nie jest możliwe, podejmowane są próby ograniczenia jego negatywnych skutków.

Artykuł koncentruje się na przedstawieniu istoty konfliktu interesów w nauce, pokazaniu pewnych przykładów tego zjawiska wraz z jego destrukcyjnymi konsekwencjami oraz zarysowania modelu zarządzania ryzykiem pojawienia się tendencyjności w badaniach naukowych. Głównym celem pracy jest przedstawienie argumentów na rzecz postulatu głoszącego, iż świadomość konfliktu interesów polegająca zarówno na ogólnej wiedzy obejmującej tę problematykę, jak i trafnej ocenie własnego usytuowania wobec zagrożenia braku obiektywizmu powinna stanowić minimum etyczne każdego pracownika naukowego.

\section{Konflikt interesów w nauce}

Pojęcie konfliktów interesów jest szerokie i obejmuje rozmaite ich rodzaje, dlatego dla uniknięcia nieporozumień trzeba zaznaczyć, że sytuacje, w których dwa lub więcej odrębnych podmiotów dąży do osiągnięcia tego samego celu są poza zakresem naszych rozważań. Nie chodzi zatem o sytuację, w której na przykład dwie firmy wytwarzające podobne produkty chcą zdobyć tego samego klienta, czy dwie jednostki naukowe ubiegają się o ten sam grant badawczy. Tego typu konflikty są immanentną cechą gry rynkowej i w określonych okolicznościach mogą sprzyjać ładowi gospodarczemu. Istnieją natomiast konflikty, które są dla owego ładu, a także dla porządku społecznego szczególnie destrukcyjne i właśnie te są przedmiotem naszej uwagi. Chodzi o sytuację, w której jeden podmiot jest z jakichś powodów skłaniany do działań w niezgodnych kierunkach. A więc, konflikt interesów ma miejsce wówczas, gdy człowiek (lub organizacja) zobowiązany jest do podwójnej lojalności, czyli gdy jego interes (własny lub interes podmiotu, wobec którego ma zobowiązania) jest lub może być nie do pogodzenia $\mathrm{z}$ interesem innego podmiotu, wobec którego także powinien być lojalny². Owa podwójna lojalność, czyli

\footnotetext{
${ }^{1}$ M.W. Grabski, Uczciwość i wiarygodność nauki. Praktyka, „Nauka” 2009, nr 2, s. 37-59.

${ }^{2}$ A. Lewicka-Strzałecka, Konflikt interesów [w:] Biznes, etyka, odpowiedzialność, red. W. Gasparski, WN PWN, Warszawa 2012, s. 249-288.
} 
konflikt interesów w nauce przejawia się w sytuacji, $w$ której względy finansowe lub inne korzyści osobiste moga zaburzyć lub sprawiać wrażenie, że zaburzaja, profesjonalny osąd danej osoby w podejściu do badania naukowego ${ }^{3}$.

Przykładem takiego konfliktu interesów jest sytuacja profesora Iksińskiego, który dostał do recenzji pracę doktorską, będącą dziełem syna jego kuzynki. Z jednej strony jako rzetelny opiniodawca powinien kierować się normą niezależności, czyli starać się przedstawić obiektywną opinię. Z drugiej strony, silna norma społeczna, obecna w naszej kulturze (i nie tylko) nakazuje mu działać na rzecz swego krewnego, czyli sporządzić recenzję pozytywną, a przede wszystkim z pozytywną konkluzją. Jeżeli krewny napisał dobrą pracę - co przecież może się zdarzyć - profesor Iksiński postąpi w zgodzie z obiema powinnościami. Jeżeli natomiast praca krewnego nie spełnia wymaganych standardów, to oceniając ją pozytywnie sprzeniewierzy się wartościom naukowym, w przeciwnym wypadku, narazi się na niechęć ze strony rodziny. Ten przykład pokazuje, że znajdowanie się w sytuacji konfliktu interesów nie musi, ale może prowadzić do nielojalności.

Człowiek (lub organizacja) może znaleźć się w sytuacji konfliktu interesów na skutek zewnętrznych okoliczności lub w wyniku własnych działań. Ta pierwsza możliwość dotyczy profesora Iksińskiego, któremu instytucje zewnętrzne przysłały prace do recenzji, natomiast jeżeli jednostka naukowa przyjmuje wsparcie finansowe od firmy, której oddziaływanie na środowisko naturalne ma oceniać, to stawia się w sytuacji konfliktu interesów na własne życzenie. Interes może mieć charakter finansowy lub pozafinansowy. Jeżeli badacz ma ocenić skuteczność leku produkowanego przez firmę, w której ma on udziały, wówczas jego interes ma charakter finansowy. Natomiast interes profesora Iksińskiego mającego napisać recenzję pracy krewnego polega na podtrzymaniu pozytywnych relacji z rodziną i nie ma natury finansowej.

\section{Efekt sponsora}

Finansowy konflikt interesów w nauce jako łatwiejszy do zidentyfikowania, ze względu na mierzalność interesu finansowego stał się przedmiotem licznych analiz. Większość z nich wskazuje na różnice wyników między badaniami finansowanymi ze środków prywatnych i publicznych, polegające na tym, że te pierwsze na ogół współgrają $\mathrm{z}$ interesem sponsora ${ }^{4}$. Zjawisko to określane jest jako efekt sponsora (funding effect) i towarzyszy mu hipoteza tendencyjności przeprowadzonych badań $^{5}$. Efekt sponsora został uprawdopodobniony między innymi w badaniach nad:

\footnotetext{
${ }^{3}$ S. Krimsky, Nauka skorumpowana?, PIW, Warszawa 2006, s. 197.

${ }^{4}$ J.E. Bekelman, Y. Li, C.P. Gross, Scope and Impact of Financial Conflicts of Interest in Biomedical Research: A Systematic Review, „The Journal of American Medical Association” 2003, vol. 289, nr 4, s. $454-465$

${ }^{5}$ S. Krimsky, op. cit.
} 
wpływem palenia na możliwości poznawcze człowieka ${ }^{6}$, wpływem biernego palenia na $z_{\text {drowie }}^{7}$ oraz wpływem opakowań plastikowych wyprodukowanych na bazie bisfenolu A (BPA) na przechowywaną w nich żywność ${ }^{8}$.

Badania nad konfliktami interesów w nauce pozwalają zidentyfikować liczne przykłady potencjalnych skutków tego zjawiska, które okazały się destrukcyjne w wymiarze jednostkowym i społecznym. Przykłady te pochodzą z takich dziedzin jak przemysł tytoniowy, bezpieczeństwo produktów, ochrona środowiska, toksyczne wyziewy, skuteczność i działania uboczne leków, zmiany klimatu, ekonomia i finanse. Chociaż nie da się wykazać przyczynowo-skutkowej zależności między osobistą korzyścią badaczy czy interesem biznesu sponsorującego określone badanie a jego wynikiem, efekt sponsora jest coraz mocniej potwierdzany w sensie statystycznym. Nie ma zatem pewności, ale istnieje duże prawdopodobieństwo, że ten kto płaci ma decydujący wpływ na wyniki badań. Ten uniwersalny mechanizm ilustrują dwa poniższe przykłady prac naukowych mających daleko idące konsekwencje.

Przykład pierwszy pochodzi z obszaru medycyny, gdzie konflikt interesów dostrzeżono już dosyć dawno. Otóż opublikowany w 1966 r. bestseller Feminine Forever pomógł przekonać wielu lekarzy i miliony ich pacjentek, że estrogenowa terapia postmenopauzalna jest nie tylko pomocna, ale wręcz niezbędna dla kobiet do normalnego funkcjonowania. Autor tej książki, amerykański ginekolog dr Robert A. Wilson utrzymywał, że menopauza nie jest stanem naturalnym, ale chorobą, która należy zwalczać za pomocą hormonalnej terapii zastępczej i w znacznym stopniu przyczynił się do jej upowszechnienia wśród amerykańskich kobiet. Jednak długofalowe badania nad tą terapią opublikowane w „Journal of the American Medical Association” w 2002 r. ${ }^{9}$ wykazały, że jej ujemne strony, w szczególności związane z nią ryzyko choroby nowotworowej znacznie przeważa nad korzyściami. Po wielu latach, na skutek dziennikarskiego śledztwa okazało się również, że książka Wilsona i jej szeroka promocja były finansowane przez firmę farmaceutyczną Wyeth, producenta leku.

Przykład drugi pochodzi z obszaru akademickiej ekonomii, będącej tą dziedziną nauki, w której ryzyko konfliktów interesu zaczęto dostrzegać stosunkowo niedawno. Dotyczy Islandii, uchodzącej na początku obecnego wieku za spokojny, zamożny i demokratyczny kraj, dobrze rozwinięty gospodarczo, cieszący się niskim poziomem korupcji. Kiedy do opinii publicznej zaczęły przenikać głosy zaniepokojenia dotyczące nadmiernego zadłużenia sprywatyzowanych banków, Islandzka Izba Handlowa i międzynarodowe korporacje, zleciła opracowane raportu na temat

\footnotetext{
${ }^{6}$ C. Turner, G.J. Spilich, Research into Smoking or Nicotine and Human Cognitive Performance: Does the Source of Funding make a Difference?, „Addiction” 1997, vol. 92, nr 11, s. 1423-1426.

${ }^{7}$ D.E. Barnes, L.A. Bero, Why Review Articles on the Health Effects of Passive Smoking Reach Different Conclusions, „The Journal of American Medical Association” 1998, vol. 279, nr 19, s. 1566-1570.

${ }^{8}$ F.S. vom Saal, S.C. Nagel, B.G. Timms, W.V. Welshons, Implications for Human Health of the Extensive Bisphenol A Literature Showing Adverse Effects at Low Doses: A Response to Attempts to Mislead the Public, ,Toxicology” 2005, vol. 212, nr 2-3, s. 244-252.

${ }^{9}$ Writing Group for the WHI Investigators, Risks and benefits of estrogen plus progestin in healthy postmenopausal women: principal results from the Women's Health Initiative randomized controlled trial, „The Journal of American Medical Association” 2002, vol. 288, nr 3, s. 321-333.
} 
systemu finansowego Islandii. Głównym autorem tego opracowania był Frederic Mishkin, profesor Columbia Business School. Z raportu wynikało, że banki są kompetentnie zarządzane, nadzór finansowy działa sprawnie i Islandia jest wspaniałym miejscem do inwestowania. Pod koniec 2008 roku nastąpił ogólnonarodowy krach, trzy największe banki upadły, ponieważ zapożyczyły się na 120 miliardów dolarów - 10 razy więcej niż wynosiło PKB Islandii. Okazało się, że apologetyczne opracowanie na temat systemu finansowego, mające powstrzymać głosy niepokoju opinii publicznej i uśpić jej czujność, nie było rzetelne. Mishkin, przygotowując je, opierał się na oficjalnych danych podsuniętych przez Izbę Handlową, czyli tę instytucję, której prawidłowość funkcjonowania miał zweryfikować. Płacącym niebagatelne, bo wynoszące 124 tysiące dolarów honorarium za kontrolę była instytucja kontrolowana. Fakt ten nie był w publikacji raportu ujawniony.

Konflikt interesów w obszarze nauk medycznych został rozpoznany znacznie wcześniej i lepiej niż w ekonomii i chociaż w dalszym ciągu może być źródłem nieprawidłowości, to świadomość jego możliwych konsekwencji, zarówno wśród badaczy jak i opinii publicznej prowadzi do przeciwdziałania im na drodze regulacji prawnych i samoregulacji. Natomiast sfera akademickiej ekonomii dosyć długo umykała uwadze pod kątem uwikłań jej przedstawicieli w konflikty interesów. Przypuszcza się, iż owo uwikłanie było jedną z przyczyn tego, że ekonomiści nie przewidzieli kryzysu finansowego z roku 2008. Analiza aktywności dziewiętnastu prominentnych ekonomistów afiliowanych na prestiżowych uniwersytetach wykazała, że prawie wszyscy byli na różne sposoby powiązani z instytucjami finansowymi ${ }^{10}$. Jednak nie ujawniali tych powiązań, kiedy jako eksperci uczestniczyli w debacie o kształcie reform systemu finansów i w istotny sposób wpływali na decyzje o jego deregulacji, zaś siła tego wpływu była poparta wysokim autorytetem ich akademickich pozycji.

\section{Prawne i środowiskowe uregulowania i ich realizacja $w$ praktyce}

Problemy konfliktu interesów w nauce zaczęły być dostrzegane w naszym kraju. Pewne sytuacje są regulowane przez prawo, na przykład znowelizowana w 2014 roku ustawa o stopniach i tytule naukowym stanowi, że recenzentem pracy doktorskiej nie może być osoba zatrudniona w placówce, w której przeprowadzany jest przewód $^{11}$. Innym przykładem takiej regulacji jest wprowadzony w 2011 roku zakaz

\footnotetext{
${ }^{10}$ J. Carrick-Hagenbarth, G.A. Epstein, Dangerous interconnectedness: economists' conflicts of interest, ideology and financial crisis, ,Cambridge Journal of Economics” 2012, vol. 36, nr 1, s. 43-63.

${ }^{11}$ Art. 20. 5. Ustawy z dnia 14 marca 2003 r. o stopniach naukowych i tytule naukowym oraz o stopniach i tytule w zakresie sztuki głosi: W przewodach doktorskich powołuje się co najmniej dwóch recenzentów spośród osób zatrudnionych w szkole wyższej lub jednostce organizacyjnej innej niż ta, której pracownikiem jest osoba ubiegająca się o nadanie stopnia doktora i niebędacych czlonkami rady jednostki organizacyjnej przeprowadzajacej przewód.
} 
zależności służbowej między spokrewnionymi pracownikami akademickimi ${ }^{12}$. Ma on celu przeciwdziałać faworyzowaniu członków rodziny opartemu na pozamerytorycznych względach, utrudniającemu realizację akademickiej kariery osobom z zewnątrz i w dalszej konsekwencji wpływającemu hamująco na rozwój nauki. Okazuje się jednak, że w pewnych wypadkach placówki naukowe mają kłopot z interpretacją i egzekwowaniem tego zakazu, czasem udaje się go obejść.

Jednocześnie wiele sytuacji znajduje się poza zasięgiem sztywnej legislacji. Ich rozwiązań możemy poszukiwać w tzw. miękkim prawie, czyli zbiorach dobrych praktyk, kodeksach etycznych, wewnętrznych regulaminach. Kodeks etyki pracownika naukowego ${ }^{13}$ wymienia niezależność (od zewnętrznych wpływów na prowadzenie badań, zarówno wobec zlecających badania czy ekspertyzy, jak też od wpływów ze strony politycznych, ideologicznych lub biznesowych grup nacisku) jako jedną z uniwersalnych wartości etycznych w pracy naukowej. Unikanie konfliktu interesów zostało w tym dokumencie uznane za jedną z dobrych praktyk, zaleca się ujawnianie potencjalnych konfliktów interesów przez autorów publikowanych dzieł (3.3.9), a także odmowę recenzowania dzieła lub opiniowania projektu w sytuacji konfliktu interesów (3.4.2), nie precyzując na czym konflikt może polegać. W innych regulacjach sytuacja konfliktu interesów jest przedstawiana bardziej szczegółowo. W opublikowanym w 2011 r. przez Ministerstwo Nauki i Szkolnictwa Wyższego dokumencie Dobre praktyki w procedurach recenzyjnych $w$ nauce ${ }^{14}$ stwierdza się, że konflikty interesów mogą wystąpić z racji różnorodnych powiązań między autorem dzieła, projektu lub innego rodzaju dokumentu i recenzentem. Moga one mieć charakter rodzinny, towarzyski, zawodowy, szczególnie w kontekście współpracy, zależności służbowej, możności decydowania o sprawach istotnie ważnych dla recenzenta, mogą to być więzi zarówno pozytywne jak i negatywne. Konflikt interesów rodzi także sytuacja bliskich powiązań, zwłaszcza finansowych łączących podmiot zamawiający recenzję $\mathrm{z}$ recenzentem. W przypadku opiniowania działalności jednostek naukowych, recenzent nie powinien ani w czasie wykonywania recenzji, ani wcześniej być z nią związany umową o pracę lub inną długotrwałą współpracą. W bardziej kategorycznej formie taką normę zawiera Kodeks Etyki Polskiej Komisji Akredytacyjnej ${ }^{15}$ zabraniający podejmowania czynności oceniających daną uczelnię członkowi (ekspertowi) PKA, jeżeli on (lub bliska mu osoba) jest lub był w niej zatrudniony lub z którą łączą go jakiekolwiek umowy cywilnoprawne, o ile nie upłynął okres 5. lat. Nie wolno mu także podejmować tych

\footnotetext{
${ }^{12}$ Art.118.7 Ustawy z dnia 27 lipca 2005 r. prawo o szkolnictwie wyższym głosi: Pomiędzy nauczycielem akademickim a zatrudnionym w tej samej uczelni jego matżonkiem, krewnym lub powinowatym do drugiego stopnia włacznie oraz osoba pozostająca w stosunku przysposobienia, opieki lub kurateli nie może powstać stosunek bezpośredniej podległości służbowej. Nie dotyczy to osób pełniacych funkcje organów jednoosobowych uczelni, dla których ustawa przewiduje powoływanie ich $w$ drodze wyborów.

${ }^{13}$ Kodeks etyki pracownika naukowego został uchwalony przez Zgromadzenie Ogólne PAN 13 grudnia 2012 r. http://www.nauka.gov.pl/publikacje-ministerstwo/kodeks-etyki-pracownika-naukowego.html (data dostępu: 09.06.2016).

${ }^{14}$ Dobre praktyki w procedurach recenzyjnych w nauce, http://www.nauka.gov.pl/publikacje-ministerstwo/archiwum,1.html (data dostępu: 09.06.2016).

${ }^{15}$ http://www.pka.edu.pl/ (data dostępu: 09.06.2016).
} 
czynności wobec uczelni, której siedziba, filia, wydział zamiejscowy bądź zamiejscowy ośrodek dydaktyczny znajdują się w tej samej miejscowości, w której zlokalizowana jest siedziba uczelni zatrudniającej członka (eksperta) PKA lub bliska mu osobe.

W praktyce standardy eksperckiej niezależności nie zawsze bywają przestrzegane. Podczas kontroli Naczelnej Izby Kontroli w Ministerstwie Nauki i Szkolnictwa Wyższego stwierdzono ${ }^{16}$, iż w składzie 21 zespołów (75\%) Rady Nauki znalazły się osoby będące pracownikami jednostek naukowych ocenianych przez dany zespół (w tym zespołów jednoosobowych). Sytuacja, w której oceniający są ocenianymi mogła niekorzystnie wpływać na przebieg prac parametryzacyjnych oraz obiektywizm oceny. Okazuje się, że niezależności ekspertów nie gwarantują deklaracje o bezstronności i braku konfliktu interesów podpisywane przez członków zespołów opiniodawczo-doradczych przystępujących do oceny wniosków o przyznanie środków finansowych na naukę.

Przykładem braku świadomości istoty konfliktu interesów zarządzających organizacją konkursów naukowych jest prośba o sporządzenie recenzji wniosku grantowego skierowana do badacza, który aplikował o środki finansowe w tym samym konkursie ${ }^{17}$. Organizatorzy próbowali rozwiać etyczne wątpliwości sygnalizowane przez potencjalnego recenzenta zaznaczając, że konflikt interesów ma miejsce wówczas, gdy pomiędzy recenzentem a wnioskodawcą i kierownikiem projektu zachodzą zależności służbowe (np. to samo miejsce pracy, podległość służbowa) lub recenzent bierze udział w realizacji projektu, którego dotyczy prośba o recenzję. Nie dostrzegali natomiast, że recenzent oceniający swoich konkurentów ma interes w obniżaniu wartości ich zamierzeń badawczych, co może wpłynąć na brak obiektywizmu jego oceny. Proponowanie człowiekowi, by miał wpływ na pozycjonowanie innych osób ubiegających się o środki finansowe z ograniczonej puli pieniędzy, o które on także się stara oznacza, by był, pośrednio, ale jednak, sędzią we własnej sprawie. Oparcie się tej pokusie może prowadzić do zmniejszenia własnych szans w tym konkursie.

\section{Zarządzanie konfliktem interesów: model trzech $\mathbf{U}$}

Istotną rolę w ograniczaniu negatywnych skutków konfliktów interesów pełni samoregulacja odwołująca się z jednej strony do pewnych wyższych wartości, zaś z drugiej do sankcji dyscyplinarnych. Samoregulacja jest szczególnie dobrze rozwinięta w sferze gospodarczej, ponieważ obecnie każda większa firma, której zależy na sukcesie prowadzi politykę zarządzania konfliktami interesów. Polega ona na postawieniu pracownikom wymagań w wielu przypadkach bardziej restrykcyjnych niż prawo i egzekwowaniu ich w specyficzny sposób. Zarządzanie konfliktami

\footnotetext{
${ }^{16}$ Kontrola NIK „Wykorzystanie środków publicznych na naukę” objęła lata 2009-2011, https://www. nik.gov.pl/plik/id,4361,vp,6190.pdf (data dostępu: 09.06.2016).

${ }^{17}$ Sędzią we własnej sprawie? List prof. K. Jaskułowskiego o recenzjach NPRH, http://obywatelenauki.pl/2013/11/list-prof-jaskulowskiego/ (data dostępu: 09.06.2016).
} 
interesów opiera się na trzech filarach: uświadamianie, unikanie, ujawnianie. Ten rodzaj zarządzania, czyli model trzech U może również znaleźć zastosowanie w nauce.

Pierwszy jego filar, czyli uświadamianie polega na przekazaniu pracownikom umiejętności identyfikacji konfliktu interesów w szczególnych warunkach funkcjonowania danej organizacji oraz określania łączącego się z nim ryzyka. Ryzyko związane jest nie tylko z faktycznymi szkodami jakie może spowodować konflikt interesów, ale także z potencjalnymi stratami spowodowanymi nadwyrężeniem wizerunku. W nauce to nadwyrężenie wizerunku polega na podejrzeniu o stronniczość, które może zniszczyć społeczną wiarę w wyniki badań naukowych. Ważnym postulatem jest nie tylko unikanie stronniczości, ale nie dopuszczanie do podejrzeń o stronniczość. Budowanie tego filara jest w środowisku naukowym wyjątkowo trudne, ponieważ jak zauważa wybitny znawca i badacz konfliktów interesów Sheldon Krimsky, typowy naukowiec nie przyjmuje do wiadomości, że jakikolwiek osobisty interes finansowy związany z przedmiotem prowadzonych przez niego badań mógłby mieć wplyw na jego podejście do badania ${ }^{18}$. Naukowcy z reguły są przeświadczeni o swojej bezstronności i wszelkie podejrzenia o jej brak traktują jako nieuzasadnione.

Kolejny filar to unikanie polegające na zakazie pewnych działań, na przykład niektóre organizacje zakazują swoim pracownikom prowadzenia transakcji z macierzystą firmą, działań konkurencyjnych i wielu innych. Niektóre placówki naukowe nie pozwalają uczestniczyć badaczom w tych projektach, których wynik mógłby być dla nich interesujący finansowo. Unikanie konfliktu interesu może także przejawiać się w niedopuszczaniu do pewnych ryzykownych powiązań, na przykład przy dobieraniu recenzentów. Może ono polegać na autoselekcji, czyli potencjalni opiniodawcy sami deklarują swoją bezstronność. W sytuacji dużej liczby tekstów, referatów, które trzeba poddać recenzji stosuje się komputerowe metody analizy potencjalnych powiązań, na przykład bada się podobieństwo adresów internetowych czy afiliacji. Jeszcze inny sposób polega na ustalaniu grup współautorów, po to, by dany tekst nie poszedł do recenzji do kogoś, kto w przeszłości współpracował z danym autorem. Do określania poziomu konfliktu interesów stosuje się analizę powiązań na forach społecznościowych, a więc bada się profile naukowców, w których ujawniają oni swoje powiązania z innymi badaczami.

Trzeci filar modelu zarządzania konfliktami interesów to ujawnianie. Postuluje się je wtedy, gdy zakaz unikania jest niekorzystny, trudny do zrealizowania. Ujawnienie $\mathrm{w}$ znacznym stopniu ogranicza potencjalne nadużycia, ponieważ świadomość, że powiązania danej osoby są znane otoczeniu powstrzymuje ją od działań na swoją korzyść kosztem interesu publicznego. Ujawnienie powinno być dokonane przez osobę, której konflikt dotyczy. W niektórych organizacjach ma ono charakter rutynowy i traktowane bywa jako obowiązek pracownika, zaś stopień zagrożenia konfliktem interesu oceniany jest przez osoby znajdujące się na kolejnych szczeblach hierarchii służbowej. W przypadku osób piastujących najwyższe stanowiska w firmie, ów stopień powinien być oceniany przez menedżerów do spraw etyki.

\footnotetext{
${ }^{18}$ S. Krimsky, op. cit., s. 198.
} 
Ujawnianie może mieć charakter wewnętrzny lub zewnętrzny. To pierwsze polega na poinformowaniu o konflikcie interesów przełożonych, ewentualnie kolegów w organizacji. Jednak w pewnych sytuacjach okazuje się to niewystarczające i wskazane jest ujawnianie zewnętrzne, czyli poinformowanie o konflikcie interesów opinii publicznej. Takiego ujawniania od władz wydziału medycznego Uniwersytetu w Toronto zażądali studenci zaniepokojeni zakresem wplecionej w proces dydaktyczny indoktrynacji sterowanej przez firmy farmaceutyczne. Obecnie, przed rozpoczęciem wykładu każdy wykładowca musi złożyć oświadczenie o potencjalnych konfliktach interesów, w których się znalazł, takich jak posiadane akcje, honoraria, konsultacje, członkostwo w radach nadzorczych. Wcześniej oświadczenie to było znane jedynie władzom uczelni, obecnie mają prawo je znać wszyscy studenci uczestniczący w wykładach, po to by móc ocenić, w jakim stopniu na ich treść mogło wpłynąć zaangażowanie wykładowcy ${ }^{19}$.

Polityka zewnętrznego ujawniania stosowana jest w coraz większym stopniu przez czasopisma naukowe, szczególnie biomedyczne. Standardem staje się, że autor publikujący artykuł na przykład w „Lancecie” ujawnia źródła finansowania jego badań, spółki w których ma udziały oraz sponsorów swoich wyjazdów na konferencje. Podobne wymagania stawiają również niektóre polskie czasopisma, szczególnie medyczne ${ }^{20}$.

\section{Zakończenie}

Przedstawione wyżej przykłady i wiele innych prowadzi do wniosku, że konflikty interesów godzą w bezinteresowność nauki stanowiącą jeden z filarów jej etosu, przesądzających o jej tożsamości. Bezinteresowność nauki, zdaniem Roberta Mertona, polega na tym, że niezależnie od motywów jakimi mogą kierować się jednostki - działalność naukowa jest podporządkowana szukaniu prawdy, nie zaś takim czy innym celom partykularnym ${ }^{21}$. Uczeni poszukują rzetelnej wiedzy dla niej samej, osobiste czy społeczne korzyści nie mogą być motorem takich poszukiwań. Bezinteresowność nie jest cechą przysługującą uczonym, ale normą wymuszoną instytucjonalnie poprzez wymóg intersubiektywnej kontrolowalności wyników. Wszystkie twierdzenia muszą być poddane merytorycznym kryteriom akceptacji, a zatem nie mogą nimi być względy partykularne - osobiste czy społeczne korzyści. Konflikty interesów w nauce przyczyniają się do erozji instytucjonalnej normy bezinteresowności, na której ludzie opierają zaufanie do tego komponentu ładu społecznego.

\footnotetext{
${ }^{19} \mathrm{C}$. Wiens, A. Cota, Lecturer conflicts of interest in medical school education: Raising the bar in BC, „BC Medical Journal” 2009, vol. 51, nr 4, s. 162-163, http://www.bcmj.org/mds-be/lecturer-conflictsinterest-medical-school-education-raising-bar-bc (data dostępu: 09.06.2016).

${ }^{20} \mathrm{~W}$ przypadku czasopism medycznych wynikają one z zasad opracowanych przez Międzynarodowy Komitet Redaktorów Czasopism Medycznych przyjmowanych przez liczące się periodyki.

${ }^{21}$ R.K. Merton, Teoria socjologiczna i struktura społeczna, PWN, Warszawa 1982.
} 


\section{Bibliografia}

Barnes D.E., L.A. Bero, Why Review Articles on the Health Effects of Passive Smoking Reach Different Conclusions, „The Journal of American Medical Association” 1998, vol. 279 , nr 19, s. $1566-1570$.

Bekelman J.E., Y. Li, C.P. Gross, Scope and Impact of Financial Conflicts of Interest in Biomedical Research: A Systematic Review, „The Journal of American Medical Association" 2003, vol. 289, $\mathrm{nr}$ 4, s. 454-465.

Carrick-Hagenbarth J., G.A. Epstein, Dangerous interconnectedness: economists' conflicts of interest, ideology and financial crisis, „Cambridge Journal of Economics” 2012, vol. 36, nr 1, s. 43-63.

Dobre praktyki w procedurach recenzyjnych $w$ nauce, http://www.nauka.gov.pl/publikacjeministerstwo/archiwum, 1.html.

Grabski M.W., Uczciwość i wiarygodność nauki. Praktyka. „Nauka” 2009, nr 2, s. 37-59.

Kodeks etyki pracownika naukowego, Załącznik do uchwały nr 10 Zgromadzenia Ogólnego PAN z 13 grudnia 2012 r., http://www.nauka.gov.pl/publikacje-ministerstwo/kodeks-etykipracownika-naukowego.html.

Krimsky S., Nauka skorumpowana?, PIW, Warszawa 2006.

Lewicka-Strzałecka A., Konflikt interesów [w:] Biznes, etyka, odpowiedzialność, red. W. Gasparski, WP PWN, Warszawa 2012, s. 249-288.

Merton R.K., Teoria socjologiczna i struktura społeczna, PWN, Warszawa 1982.

Najwyższa Izba Kontroli, Informacja o wynikach kontroli ,, Wykorzystanie środków publicznych na nauke”, https://www.nik.gov.pl/plik/id,4361,vp,6190.pdf.

Sędzią we własnej sprawie? List prof. K. Jaskułowskiego o recenzjach NPRH, http://obywatelenauki.pl/2013/11/list-prof-jaskulowskiego/.

Turner C., G.J. Spilich, Research into Smoking or Nicotine and Human Cognitive Performance: Does the Source of Funding make a Difference?, „Addiction” 1997, vol. 92, nr 11, s. 1423-1426.

vom Saal F.S., S.C. Nagel, B.G. Timms, W.V. Welshons, Implications for Human Health of the Extensive Bisphenol A Literature Showing Adverse Effects at Low Doses: A Response to Attempts to Mislead the Public, „Toxicology” 2005, vol. 212, nr 2-3, s. 244-252.

Wiens C., A. Cota, Lecturer conflicts of interest in medical school education: Raising the bar in BC, „BC Medical Journal” 2009, vol. 51, nr 4, s. 162-163, http://www.bcmj. org/mds-be/lecturer-conflicts-interest-medical-school-education-raising-bar-bc.

Wilson R.A., Feminine Forever, M. Evans Co, New York 1966.

Writing Group for the WHI Investigators, Risks and benefits of estrogen plus progestin in healthy postmenopausal women: principal results from the Women's Health Initiative randomized controlled trial, „The Journal of American Medical Association” 2002, vol. 288, nr 3, s. 321-333.

http://www.pka.edu.pl/ 